Villanova School of Business Economics Working Paper \#32

\title{
Alternative Work Arrangements and Job Satisfaction
}

March, 2018

Cheryl Carleton, $\mathrm{PhD}$

Department of Economics

800 E. Lancaster Ave.

Villanova University

Villanova, PA 19085

Cheryl.Carleton@Villanova.edu

ORCID: 0000-0003-0780-9171

Linked in: Cheryl Carleton

Corresponding author
Mary Kelly, PhD

Department of Economics

800 E. Lancaster Ave

Villanova University

Villanova, PA 19085

Mary.Kelly@villanova.edu 


\title{
ALTERNATIVE WORK ARRANGEMENTS AND JOB SATISFACTION
}

\begin{abstract}
There has been a rise in alternative work arrangements in recent years, with much variation in who selects these work arrangements and the reasons for doing so. Higher participation rates may stem in part from individual's needs which are not met in more traditional jobs and is reflected in the impact they have on job satisfaction. This study explores variations in job satisfaction by work arrangement, controlling for both occupation and gender for respondents to the 2006, 2010 and 2014 General Social Survey. The rise in such employment and the prospect of it continuing to rise may have implications for the structure of jobs offered by traditional firms and it may also have important implications for the social safety nets of such workers and their families given the nature of how such benefits are provided in our economy.
\end{abstract}

KEYWORDS: Job Satisfaction, Alternative work arrangements, Well-being, Quality of work life.

JEL CLASSIFICATIONS: J28, J16, J48 


\section{INTRODUCTION}

There has been a rise in alternative work arrangements in recent years with increasing numbers of people becoming self- employed as independent contractors or selecting their hours of work while working for one of several "just in time” employers such as Uber, Lyft, and TaskRabbit. Still others are on-call workers or work for temp agencies or for contractors who provide services for others. ${ }^{1}$ According to a study by Katz and Krueger (2016), the percentage of workers engaged in alternative work arrangements rose from $10.1 \%$ in 2005 to $15.8 \%$ in $2015 .^{2}$ The types of jobs in these categories vary partly by whether they are professional occupations or nonprofessional occupations. They vary by industries and include jobs that require a high level of skill and knowledge as well as those that require less of an investment in human capital. They vary by job characteristics (pay, benefits, predictability of income, upward mobility, ability to adjust time, nature of the job) and by demographics (age, gender, family size, income). And, they have changed over time. For example, in 2005, the BLS (2005) found that independent contractors were more likely to be in construction and professional or business services. They were more likely to be male, older, white, and have a higher level of education. Temp agency workers, while also well-represented in professional and business services industries, were more likely to be female, young, black or Hispanic/Latino, and less educated. By 2015, Katz and Krueger (2016) found that the share of alternative workers in most industries had increased, although construction and professional services still had the highest share of alternative workers. ${ }^{3}$ They also found an increase in the likelihood of being in alternative work

\footnotetext{
${ }^{1}$ The BLS defines alternative work as consisting of independent contractors who obtain customers on their own, oncall workers who are on standby until called to work, temporary help workers who are paid by a temp agency, and contract-company workers who are work for a company who contracts out their services.

${ }^{2}$ A 2016 McKinsey Global Institute study reports that 20 to 30 percent of the working age population in the United States and the EU-15 work in independent jobs.

${ }^{3}$ By sector, the number of workers in alternative work arrangements more than doubled to $11 \%$ in manufacturing, rose to $16 \%$ in health and education, and quintupled to $10 \%$ in public administration.
} 
among older workers and those with more education. Among women, they found that the proportion holding such jobs jumped from $8 \%$ to $17 \%$.

McKinsey Global Institute (2016) suggests that there exists a significant growth potential of workers in these types of alternative work arrangements in the years ahead, with both demand and supply side factors playing a role. Assuming firms can find workers when needed, employers may expect improvements in productivity and flexibility by better matching labor to just-in-time consumption. On the supply side, one predictor of their continued growth may be the worker's level of job satisfaction, particularly in contrast to that of workers in regular work arrangements. If job satisfaction is higher in some types of alternative work arrangements we may well see individuals continuing to take advantage of these opportunities, either as a supplement or as an alternative to regular jobs.

This study will specifically investigate the impact on job satisfaction of workers by work arrangement, by gender, and by whether or not the occupation is professional or nonprofessional. ${ }^{4}$ While the varying impact on job satisfaction itself is interesting, to the extent that some types of alternative work arrangements provide greater job satisfaction in contrast to regular jobs, it may be an indication that we can expect to see a continued increase in such work arrangements in the future as these workers are seemingly willing to forego employer-provided benefits for greater flexibility and control. Such an increase has important implications for these workers and their families in terms of pensions, unemployment insurance and health insurance. It may also have an impact on firms who need to hire or retain workers, particularly women, for

\footnotetext{
${ }^{4}$ When studying self-employment Budig (2006) notes that such jobs have increased in the most and the least rewarded occupations, thus lumping all self-employed workers together in one category misses a lot of heterogeneity. The same is likely for other types of alternative work arrangements. For this study, we use the Occupational classifications to classify the observations into managerial and professional vs. non-managerial, nonprofessional.
} 
more regular jobs. ${ }^{5}$ If job satisfaction is the same or lower for workers in alternative work arrangements relative to those in regular jobs, the assumption might be that workers, if given a choice, would prefer regular employment with benefits and perceived job security. But, given the changing nature of work, that choice might not exist for some occupations.

\section{LITERATURE REVIEW}

Having a job is a key determinant of well-being, yet, the type of work can contribute to variation in job satisfaction (van Praag, Frijters, and Ferrer-i-Carbonell 2003). ${ }^{6}$ Specific to alternative work arrangements, utility or disutility can depend on what workers value and how they perceive potential benefits and costs. For example, a benefit such as flexible hours will appeal to those seeking to balance work with life-cycle events such as attending school or taking care of children (Polivka 1996; Vosko, Zukewich, and Cranford 2003). Other possible reasons to engage in non-traditional types of work include greater autonomy, additional income, opportunities to be exposed to a wider variety of projects and develop skills, and stepping stones to desired permanent job placements (Hardy and Walker 2003; Tan and Tan 2002; Morris and Vekker 2001; Booth, Francesconi, and Frank 2002). Negative aspects to alternative work arrangements may include lower wages, less job security, unpredictable work hours, lack of access to established systems of social insurance, and potentially less investment in human capital development (Booth, Francesconi, and Frank, 2002).

By work type, the BLS (2005) found that $82.3 \%$ of independent contractors preferred their alternative work arrangement to traditional work, while only 46.1 and 32.1 percent of on-

\footnotetext{
${ }^{5}$ Much has been written about firms losing women workers as they move up the career ladder when family responsibilities increase.

${ }^{6}$ The three most important contributors of well-being are good health, financial security, and having a job. These findings are supported by other studies (see for example Wooden and Warren 2004; Clark 1994).
} 
call workers and temp agency workers, respectively, reported the same. A possible explanation for higher job satisfaction among independent contractor is that they are more likely to have voluntarily chosen their job arrangement (Tan and Tan 2002; Hardy and Walker 2003; Krausz, Brandwein, and Fox 1995; Ellingson, Gruys, and Sackett 1998). They are more likely to have high-skills and view their jobs as means to permanent work (Houseman 2001; Booth, Francesconi and Frank 2002). They are better able to accumulate and sell their skills across organizations and, as a result, enjoy work flexibility, autonomy, and higher wages (Marler, Barringer, and Milkovich 2002). By contrast, on-call and temp agency workers with low-skills are more likely to be involuntarily employed, suffer from a large wage and fringe benefit penalty, and are often hired to meet peaks in demand with fewer opportunities for permanent employment (Houseman 2001; Marler, Barringer, Milkovich 2002; Watson 2005; Bardasi and Francesconi 2004; Booth, Francesconi, and Frank 2002; Wilkin 2013).

The weights workers place on job attributes are influenced by such factors as the content of the job, the individuals' "positions in life", and whether the choice of the work arrangement is voluntary or involuntary (Ellingson, Gruys, and Sackett 1998; Morris and Vekker 2001; de Graaf-Zijl 2012). ${ }^{7}$ Occupational differences, such as the color of the work-shirt collar (white, blue, pink), interactive characteristics with gender, such as age, income, marital status, and number and ages of children, and the non-standard work type (independent contractor versus oncall vs. temp agency) will motivate work preferences and may impact job satisfaction. Specifically, workers in professional occupations typically enjoy higher pay and greater control of their work and decision-making which contribute to higher job satisfaction (Rollero, Fedi, and

\footnotetext{
7 "Positions in life" include marital status, number of children, age, and educational aspirations. Involuntary reasons may include job loss or the inability to find permanent work. Morris and Vekker (2001) suggest that it is the lack of good permanent jobs more than the desire for flexibility that pushes workers into temporary positions.
} 
De Piccoli 2016; Van der Meer and Wielers 2013). Given social norms around household responsibilities, women often choose alternative work arrangements for family-centered reasons, like child-care or elderly-care, which confounds their feelings about job satisfaction. ${ }^{8}$ By work type, female independent contractors have a stronger preference for this type of work because the flexibility and autonomy it offers contributes to both family care and financial needs. Female temporary agency workers, on the other hand, are less satisfied with their jobs as they often “settle for” rather than prefer the employment arrangement (Marler and Moen 2005). Their motivation is to have another source of "breadwinning" in the family rather than choosing it for family-related flexibility (Marler and Moen 2005).

When surveyed, workers often rank job security as an important determinant of job satisfaction (see for example Chadi and Hetschko 2013; Sverke, Hellgren and Näswall 2002; de Graaf-Zijl 2012). Specifically, they report higher job satisfaction when the perceived risk of losing one’s job is lower (Origo and Pagani 2009; Green and Heywood 2011; Theodossiou and Vasileiou 2007). ${ }^{9}$ But, while non-standard jobs are generally less secure than permanent ones, employability is more a function of demand for workers' skills and knowledge (Silla. Gracia, and Peiró 2005; Gracia et al. 2011). And, since demand influences pay, hours, and work autonomy, more pay and more control over work improves job satisfaction and contributes to findings that on-call and temp agency workers are typically less satisfied with their jobs than independent contractors and permanently-employed workers (Origo and Pagani 2009; de Graaf-Zijl 2012;

\footnotetext{
${ }^{8}$ Tannous amd Smith (2013) suggest that dependent care responsibilities disproportionately fall on women and why they are more likely than men to engage in part-time work. This “choice” has a significant impact on women’s current and future income.

${ }^{9}$ Origo and Pagani (2009) found this to be true regardless of the contract length (temporary vs. permanent). Green and Heywood (2011) found that when they controlled for job security, flexible contracts had a positive influence on overall job satisfaction. The results held for both genders.
} 
Wilkin 2013; Green, Kler, and Leeves 2011). ${ }^{10}$ Because men, on average, choose work for work-centered reasons, like status, higher income, and comradery, those in on-call and temp agency jobs tend to experience lower job satisfaction than their counterparts in permanent work (Buddelmeyer, McVicar, and Wooden 2015). The differential can be even larger if the hours are part-time (Green, Kler, and Leeves 2010). ${ }^{11}$ The same cannot be said for women (Buddelmeyer, McVicar, and Wooden 2015) which suggests that men, particularly those in low-skill occupations, value job security more than women (de Graaf-Zijl 2012).

For many standard and non-standard workers, however, its flexibility, predictability, and control over hours that are more important to job satisfaction than the number of hours worked. (Wooden, Warren, and Drago 2009; Golden, Henley, and Lambert 2013; Fujimoto, Azmat, and Härtel 2013; Gracia et al. 2011; McNall, Masuda, and Nicklin 2010). And, in fact, workers with flexible schedules, both male and female, may earn a wage premium (Winder 2009). ${ }^{12}$ But, when flexible work schedules become erratic and unpredictable, there is greater disruption to family and social lives and women, particularly those in on-call, often part-time, low-wage jobs, experience a greater reduction in well-being (Jacobs and Padavic 2015; Henley and Lambert 2014; Bohle et al. 2004)

\section{MODEL AND ANALYSIS}

\footnotetext{
${ }^{10}$ Houseman (2001) points to the 1995/1997 CPS data that showed that over half of on-call workers and two-thirds of temp agency workers would prefer regular work.

${ }^{11}$ By type of work, part-time on-call workers are likely to be the least satisfied because, the lack of hours accompanies weak opportunity for skill development, and concern with job and income security (Green, Kler, and Leeves 2010; Warren 2004). Warren (2004) found that women in part-time manual jobs were distinctly disadvantaged financially which impinged on their ability to achieve work-life balance. Yet, Wooden and Warren (2004) found that the negative association between casual employment and job satisfaction was restricted to fulltime workers, especially men.

${ }^{12}$ Winder (2009) found that the return to flexibility was twice as large for men than women. Some of the difference is attributed to women having less authority and autonomy in their jobs.
} 
This study builds on other models of job satisfaction which relate job satisfaction to utility (see Clark 1997; Sloane and Williams 2000; Green and Heywood 2011; Carleton and Clain 2012). It is assumed that individuals select their work type and occupation along with other uses of their time, in order to maximize their utility, subject to various constraints that they face. Utility is measured by job satisfaction, where utility is a function of individual characteristics $\left(\mathrm{X}_{\mathrm{i}}\right)$, job characteristics $\left(\mathrm{X}_{\mathrm{j}}\right)$, occupation $\left(\mathrm{O}_{\mathrm{k}}\right)$ and work type $\left(\mathrm{T}_{\mathrm{L}}\right)$ Eq (1): $\quad U=f\left(X_{i}, X_{j}, O_{i}, T_{i}\right)$

The variables included in the individual and job characteristics follows that of other researchers, but here we have extended the set of control variables to include both work type and the occupation of the individual. Job satisfaction may vary by work type as some work arrangements allow the potential for a great deal of flexibility and control, such as contract workers or being self-employed, others may provide more assured work and benefits, such as regular jobs, and others, such as work for a temporary agency, may provide fewer benefits and little control over what one does, but provide necessary income. Job satisfaction may also vary by occupation. Those in professional occupations are more likely to perceive their work as part of a career path with opportunities to gain experience and skills along the way; thus choosing an alternative work arrangement may have been one opportunity among many to advance a career. Those in nonprofessional occupations may have had fewer alternative jobs to choose from and may have selected it because it was the only job available or the only one that allowed them needed flexibility or income.

In addition, given the still prevalent difference in roles in the home for men and women, as well as gender schemas (Marler and Moen 2005) these outcomes may also vary by gender. The expectation that women are disproportionately responsible for assuring that home tasks and 
the needs of family members are met might lead to greater job satisfaction associated with work arrangements that allow flexibility to meet such needs regardless of whether the occupation is professional or nonprofessional.

\section{DATA AND DESCRIPTIVE STATISTICS}

This study utilizes data from the 2006, 2010, and 2014 General Social Survey (GSS) to examine the variation in well-being for men and women in non-standard employment relative to those in regular work. ${ }^{13}$ The three waves should capture some of the changing nature of the workforce, in addition, these waves of the GSS contain a quality of work life module that allow us to control for several aspects of the individual's job.

For the dependent variable, we use the respondent's answer to a question about job satisfaction. The job satisfaction question (JOBSAT) asked: "On the whole, how satisfied are you with the work you do?” Respondents could select from: 4) very satisfied, 3) moderately satisfied, 2) a little dissatisfied, or 1) very dissatisfied

Each survey year includes a set of core questions and topical modules of questions on a rotational basis. For the purpose of this study, we were particularly interested in participants’ answers to the question: "How would you describe your work arrangement in your main job?" Response categories included: 1) independent contractor/consultant/freelancer, obtain own customers, 2) on-call, work only when called to work, 3) paid by a temporary agency, 4) work for contractor who provides workers/services, and 5) regular, permanent employee. For our analysis, we collapsed the number of work type categories from five to three. The first category,

\footnotetext{
${ }^{13}$ The GSS survey is administered to a sample of U.S. residents every other year by the National Opinion Research Center at the University of Chicago. Its purpose is to collect demographic characteristics and attitudes. With the exception of the U.S. Census, the GSS is claimed to be the most frequently analyzed source of information about American society.
} 
INDSELF, is comprised of independent contractors and self-employed others who may have more control over the work they do and when they do it. ${ }^{14}$ The second category, NOCONTROL, consists of individuals in alternative work arrangements who have little if any control over the nature of the job or when they do it. This group consists of those who work for temp agencies, are on-call workers, or work for contractors who provide services for others. They can select not to work, but if they choose to work then they generally must abide by the parameters of the job. The final category, REGULAR, consists of those who have "regular" or more traditional jobs where they work for someone else. Over the entire sample of 3,612 responses, $531(14.7 \%)$ are independent contractors or self-employed others, 255 (7.1\%) work for a temp agency, on-call or contractor who provides services to others, and 2,826 (78.2\%) of the individuals have regular jobs.. Both the work-type and job satisfaction questions were only included in the selected Survey years.

Following the work of Budig (2006), we utilize the occupation codes to control for those who are coded as managerial or professional (MPROFF), henceforth referred to as professional, and those who are not (NMP). ${ }^{15}$ In the sample, there are 1,285 (35.6\%) professional workers, and 2,327 (64.4\%) non-professional workers. It is hypothesized that those in professional occupations may select these occupations for different reasons than those who are not and this may affect their job satisfaction or overall happiness.

We are most interested in testing for differences in well-being by gender, by work type and by occupation as the literature shows that men choose alternative work arrangements for

\footnotetext{
${ }^{14}$ Self- employed others are individuals who state that they have a regular job but are self-employed.

${ }^{15}$ Since the data covers three years, two different occupational classifications were used, the 1980 codes, and the 2010 codes. For the 1980 codes we selected the ones labeled "Managerial and Professional", which included codes 5 - 199. For the 2010 codes we also selected the ones labeled, "Managerial, Professional, and related occupations", which were codes $10-3540$.
} 
difference reasons than women and those differences may influence job satisfaction. In our sample, there are 1,733 (48\%) males and 1,878 (52\%) females. ${ }^{16}$ An examination of job satisfaction by work type, occupation, and gender is provided in Table 1.

The job-specific and personal characteristics included in the model as determinants of job satisfaction largely reflect those used by other researchers. The job-specific variables are job tenure (YEARSJOB), hours usually worked in a week (AVHOURS) if they consider their earnings compared to others doing the same type of work to be fair (FAIREARNINGS), how often the demands of the job interfere with family (JOBINT), how good the job security is (JSECURITY), how good the fringes are (GFRINGE), if they have an odd work schedule (ODDWRKSCHED), how easy it is to take time off from work (EASYTIMEOFF), and whether family interferes with work (FAMNOINTWORK). To control for personal characteristics in addition to gender, we include age (AGE), race (WHITE), marital status (MAR), health (GHEALTH), education (BAPLUS), family income (CONINCTH), number of children (CHILDS), and having two jobs (TWOJOBS). ${ }^{17}$ Also, given that the sample spans three different years, 2006, 2010 and 2014, dummy variables for 2010 and 2014 are included to capture any affects particular to a specific year which might impact job satisfaction. Appendix 1 provides a complete list of the variables. Table 2 shows the cross-tabulation statistics for the dichotomous variables and the averages for the continuous variables by work type and gender, and by work type and occupation.

\footnotetext{
${ }^{16}$ By work type and gender, there are 316 male and 215 female INDSELF workers, 155 male and 100 female NOCONTROL workers, and 1262 male and 1,564 female REGULAR workers.

${ }^{17}$ BAPLUS was dropped from the models because of high correlation with some of the other independent variables.
} 


\section{METHODOLOGY AND RESULTS}

In order to more closely examine job satisfaction by work type, by occupation, and by gender, several regressions were run, utilizing the entire sample, dividing the sample by gender, and utilizing interaction terms Given the ordinal nature of the dependent variable, the results were estimated using ordered probit, similar to that of other researchers (Clark 1997; Sloane and

Williams 2000; Donohue and Heywood 2004; Green and Heywood; Carleton and Clain 2012). While one's actual level of job satisfaction (JS*) is unobservable, it is hypothesized to be a function of the variables in equation (1), and is related to the observable level (one's reported job satisfaction, JS):

$$
\begin{aligned}
& \text { JS }=1 \text { if } \mathrm{JS}^{*} \leq 0 \\
& \mathrm{JS}=2 \text { if } 0<\mathrm{JS}^{*} \leq \mu_{1} \\
& \mathrm{JS}=3 \text { if } \mu_{1}<\mathrm{JS}^{*} \leq \mu_{2} \\
& \mathrm{JS}=4 \text { if } \mu_{2} \leq \mathrm{JS}^{*}
\end{aligned}
$$

The regression results are presented in Appendix 2. Table A presents both the ordered probit and OLS results for the entire sample, while Table B presents the ordered probit and OLS results for the regressions run by gender with interaction terms.

Turning first to Table A, we observe that the coefficients on professional workers (MPROFF), women (FEMALE), and independent contractors and self-employed (INDSELF) are positive and significant. Thus, professional workers are more satisfied with their jobs than nonprofessional workers, women are more satisfied with their jobs than men, and those who are independent contractors or self-employed are more satisfied than those who have regular jobs, even after controlling for many other factors. There is no statistically significant difference for those in work types with no control (NOCONTROL) compared to those in regular jobs. 
Given the hypothesized difference by gender, we next divided the sample by gender and ran regressions on job satisfaction separately for men and women. In addition, we created several interaction terms to pick up the hypothesized differences in job satisfaction for those in various work types and occupations. Thus, we interacted the two alternative work types (INDSELF and NOCONTROL) with occupation (MPROFF and NMP), which created four new variables.

\begin{tabular}{|l|c|c|}
\hline & Professional & Non-Professional \\
\hline $\begin{array}{l}\text { Independent Contractor or Self-Employed Other } \\
\text { (INDSELF or considered INCONTROL) }\end{array}$ & MPROFFIC & NMPIC \\
\hline $\begin{array}{l}\text { Temp Agency Worker, On-Call Worker, or One Who } \\
\text { Works For a Contractors who Provides Service to Others } \\
\text { (NOCONTROL) }\end{array}$ & MPROFFNC & NMPNC \\
\hline
\end{tabular}

Turning to the results for these equations in Table B of Appendix 2, we observe that being in an INCONTROL work type (MPROFFIC AND NMPIC) always increases job satisfaction relative to a regular job, regardless of occupation and regardless of gender. ${ }^{18}$ It is not surprising that those in professional occupations with more control have higher levels of job satisfaction, but we observe that it even increases job satisfaction for those in occupations that may require less human capital. The coefficient on NMPIC is positive and significant for both women and men, with a larger coefficient for women. Thus, being an independent contractor or self-employed is significant and positive among the nonprofessional workers. Having some control over aspects of one’s job leads to higher job satisfaction even for nonprofessional occupations compared to being in a regular job. The coefficients for work types where workers have no control over aspects of their job (MPROFFNC AND NMPNC) are insignificant for both

\footnotetext{
${ }^{18}$ With the inclusion of the interaction terms, there is no separate coefficient for INDSELF or NOCONTROL.
} 
genders and for occupation, thus these individual's job satisfaction is not statistically different than it is for those with regular jobs.

The effect of being in a professional occupation is captured by the coefficients on MPROFFIC, MPROFFNC, and MPROFF. The coefficient on MPROFF is positive and significant for the entire sample, and for women. This coefficient picks up the effect of being in a professional occupation as opposed to a nonprofessional occupation for those in regular jobs. As noted above, for the other work types, only those in work types with some control have higher satisfaction regardless of occupation; those in work types with no control have no higher job satisfaction whether they are in professional occupations or not. This holds true regardless of gender.

In terms of work type and occupation, the only differences by gender are that the coefficient on professional is significant for the women, but not the men, and the coefficient on MPROFFIC is larger for women. In terms of occupation, being in an occupation that offers some control (MPROFFIC and NMPIC), the coefficients are again larger for women. This corresponds to other studies that have just explored the differences in job satisfaction by gender. $^{19}$

\section{OTHER INDEPENDENT VARIABLES}

In addition to the impact of work type, being a professional, and gender on job satisfaction, several other variables were included in the regressions. Turning to Table B in Appendix 2, the variables where the sign and significance are the same for both men and women

\footnotetext{
${ }^{19}$ The authors also ran these same regressions, by gender, for only married individuals. The results for married women are similar to those for women in general, while for married men, MPROFF and MPROFFIC are not significant, but MPROFFNC is significant at the $10 \%$ level of significance.
} 
include age, good health, job security, job doesn’t interfere with family, good fringe benefits, workers find it easy to take time off, average hours worked, and having earnings one considers fair are all positive and significant, that is they all contribute to higher levels of job satisfaction. Variables where the impact is different, that is it is significant for one gender and not the other or positive for one and not the other include being married (MAR), having children (CHILD), being white (WHITE), having two jobs (TWOJOB), having an odd work schedule (ODDWRKSCHED) and family income (CONINCTH). Women who are married, have children, and who are white have higher levels of job satisfaction than those who are not, while none are significant for men. Having two jobs (TWOJOB), working an odd work schedule (ODDWRKSCHED, and having higher family income (CONINCTH)) leads to higher levels of job satisfaction for men, but not for women.

\section{EXTENSION: OVERALL HAPPINESS}

Similar to Green and Heywood (2011), we tested whether workers in alternative work arrangements are happier in life, relative to those in regular employment, as the benefit of flexibility to manage family and household responsibilities may offset job security, fringe benefits, and other desirable characteristics of regular employment that more directly impact job satisfaction. ${ }^{20}$ Therefore, we extended our analysis to see if work arrangements and personal and job characteristics have similar or different impacts on overall well-being than they do for job satisfaction. Overall well-being can also be utilized as a measure of utility, though it does not measure exactly the same thing that job satisfaction does. We re-ran the models using general happiness, HAPPY, as the dependent variable. In the General Social Survey, respondents were

\footnotetext{
${ }^{20}$ Wooden, Warren, and Drago (2009) found that long hours and overwork reduced life satisfaction the most as work was seen as impinging on leisure activities and the ability to meet family and community commitments.
} 
asked” Taken all together, how would you say things are these days?” They could answer: 3) very happy, 2) pretty happy, or 1) not too happy. An examination of overall happiness by work type, gender, and occupation is provided in Table 3.

Appendix 2 Table $\mathrm{C}$ presents the regression results with all the independent variables, while the results by gender with interaction terms are in Table D. In the regression based on the entire sample, the results for professional workers (MPROFF) and women (FEMALE) are similar to those for job satisfaction, but here both work type variables (INDSELF and NOCONTROL) are insignificant. When the regressions are run separately by gender and with interaction terms, being in a professional occupation (MPROFF) is only significant for the women, and for the interaction terms the only significant one is for those women in nonprofessional occupations in work types that have some control (NMPIC). For women being in a nonprofessional occupation where they are either independent contractors or are selfemployed adds to their overall happiness in comparison to those in regular jobs. For men, there is no significant difference between work types and occupations when it comes to overall happiness. For women these results hold even after controlling for several work-related and individual characteristics. Similar to job satisfaction, good health and job security contribute to a happier life for both men and women. Other factors that contribute to greater life satisfaction for both genders are marriage and higher family income. For women only, additional factors that contribute to greater life satisfaction are an easy time getting off from work (EASYTIMEOFF), and family does not interfere with work (FAMNOINTWORK). For men only, children (CHILDS), having two jobs (TWOJOB), fair earnings (FAIREARNINGS), and job doesn’t interfere with family (JOBINT) all positively impact life satisfaction, while age has a negative impact. 


\section{CONCLUSION}

These results build on the work of others who have examined job satisfaction. Some studies examine the impact of one type of employment on job satisfaction, such as Alvarez and Sinde-Cantorna (2013) who examine job satisfaction for self-employed workers. Others, such as Buddelmeyer, Vicar and Wooden (2015), use panel data from Australia to examine job satisfaction among various types of contingent employment. While they do not control for occupation as we do, they do find differences by gender and type of nonstandard employment. Green and Heywood (2011) examine differences in job satisfaction and overall life satisfaction for those in a variety of flexible employment contracts in Great Britain. They note that it is important to control for worker heterogeneity and the type of temporary contract, and that doing so provides a richer picture of their impact on both job and life satisfaction. Wilkin (2013) provides a summary of various studies which have examined job satisfaction between contingent workers and permanent workers. The author states that her findings suggest that contingent workers are not a homogeneous group, thus validating the need to control for the type of work, occupation and gender to more fully understand their impact on job satisfaction.

We find that workers who are in work types where they have more control, that is independent contractors and the self-employed, are more satisfied with their jobs than those in regular jobs. When we additionally control for whether the occupations are professional or not, this result still holds. This is not surprising for those in professional occupations, but the results hold even for those who are in nonprofessional occupations compared to those in regular jobs. On average, these are occupations that require less investment in human capital, and individuals in these occupations may select them for nonprofessional reasons (that is not to enhance promotion opportunities or wage growth). It may be that for these workers the greater flexibility 
offered by being an independent contractor or being self-employed increases their job satisfaction. Being an independent contractor or self-employed may provide these individuals with more control over what they do and when they do it whether in professional or nonprofessional occupations, leading to greater levels of job satisfaction. Workers who work for temp agencies, do on-call work, or work for contractors who provide services for others have no greater job satisfaction than those in regular jobs. These effects are similar for both men and women, with the impact being even larger for women, and the results hold even when controlling for many personal and job-related characteristics. The results for overall happiness show that for women, being in a managerial or professional occupation, and being in a nonprofessional occupation that allows them some control over what they do and when they do it increases their overall happiness compared to those in regular jobs.

The changing nature of the job market makes studies of work and its impact on job satisfaction and overall happiness more complex. The growth in the number of workers in alternative work arrangements may stem in part from individual's needs which are not met in more traditional jobs and is reflected in the impact they have on job satisfaction and overall happiness (see also Katz and Krueger 2017). To the extent that job satisfaction is greater for these workers than in regular jobs, this may indicate that we can expect to see more workers in these types of work arrangements in the future. As noted by Friedman (2014) and Pinsof (2016), such an increase can have a large impact on workers in these arrangements and their families as our economy relies on a system of employer sponsored benefits, such as health insurance, pensions, unemployment compensation and disability insurance. Many workers in these alternative work arrangements then will have no or limited access to these types of social safety nets. In addition, as noted in Pinsof (2016) this also results in decreased government tax 
revenue, unemployment insurance funds, payroll taxes and workers' compensation funds. It may be necessary for the government to rethink how some of these benefits are both provided and paid for. Moreover, it may suggest that our nation's labor laws need to be modified such that labor rights and protections are extended to all workers, regardless of employment status.

While some are concerned about the growth in these alternative work arrangements, particularly for those in nonprofessional occupations, and the potential loss in worker benefits, the results here suggest that it is not simple to enact policies that encourage one type of work type or discourage another in hopes of increasing overall well-being. Depending on one’s occupation and responsibilities (which one might argue are captured to a certain extent by gender) the impact of various work types on job satisfaction can differ. These results may also suggest that if firms wish to employ and keep workers they may need to think about the structure of the jobs they offer.

\section{Acknowledgement:}

We want to thank Kathryn Asher for her assistance in organizing the data and participants at the International Atlantic Economic Society and Eastern Economic Association conferences for their comments on earlier drafts of this paper. 


\section{References}

Alvarez, Gema, and Ana I. Sinde-Cantorna. 2013. "Self-employment and job satisfaction: an empirical analysis.” International Journal of Manpower 35 (5): 688-702.

Bardasi, Elena, and Macro Francesconi. 2004. "The impact of atypical employment on individual wellbeing: evidence from a panel of British workers.” Social Science \& Medicine 58 (9): 16711688.

Bernasek, A. and Kinnear, D. 1999. "Workers’ willingness to accept contingent employment.” Journal of Economic Issues 33 (2): 461-469.

Bohle, Philip, Michael Quinlan, David Kennedy, and Ann Williamson. 2004. "Working hours, work-life conflict and health in precarious and "permanent” employment.” Rev Saúde Pública, 38 (supl): 19-25.

Booth, Alison L., Marco Francesconi, and Jeff Frank. 2002. "Temporary jobs: stepping stones or dead ends?" Economic Journal 112 (480): F189-213.

Buddelmeyer, Hielke, Duncan McVicar, and Mark Wooden. 2015. "Non-standard 'contingent' employment and job satisfaction: a panel data analysis.” Industrial Relations 54 (2): 256-275.

Budig, Michelle J. 2006. "Intersections on the road to self-employment: gender, family, and occupational class.” Social Forces 84 (4): 2223-2239

Bureau of Labor Statistics, United States Department of Labor. 2005. “Contingent and alternative employment arrangements February 2005.”

http://www.bls.gov/news.release/pdf/conemp.pdf

Carleton, Cheryl, and Suzanne H. Clain. 2012. “Women, men, and job satisfaction.” Eastern Economic Journal 38 (3): 331-335.

Chadi, Adrian, and Clemens Hetschko. 2013. "Flexibilisation without hesitation? Temporary contracts and workers’ satisfaction.” IAAEU Discussion Paper Series 4.

Clark, Andrew E. 1997. “Job satisfaction and gender: Why are women so happy at work?” Labour Economics 4: 341-372.

Clark, Andrew E. and Oswald, Andrew J. 1994. “Unhappiness and unemployment.” Economic Journal 104: 648-659.

D'Addio, Anna Cristina, Tor Eriksson, and Paul Frijters. 2007. "An analysis of the determinants of job satisfaction when individuals' baseline satisfaction levels may differ." Applied Economics 39 (19-21): 2413-2423. 
de Graaf-Zijl, Marloes. 2012. "Job satisfaction and contingent employment." De Economist 160 (2): 197-218.

Donohue, Susan M., and John S. Heywood. 2004. "Job satisfaction and gender: an expanded specification from the NLSY.” International Journal of Manpower 25 (2):211-238.

Ellingson, Jill E., Melissa L. Gruys, and Paul R. Sackett. 1998. "Factors related to the satisfaction and performance of temporary employees." Journal of Applied Psychology 83 (6): 913-921.

Friedman, Gerald. Summer 2014. "Workers Without Employers: Shadow Corporations and the Rise of the Gig Economy.” Review of Keynesian Economics Vol. 2, No. 2: 171-188

Fujimoto, Yuka, Fara Azmat, and Charmine E.J. Härtel. 2013. "Gender Perceptions of work-life balance: management implications for full-time employees in Australia." Australian Journal of Management 38 (1): 147-170.

Golden, Lonnie, Julia Henly, and Susan Lambert. 2013. “Work schedule flexibility: a contributor to happiness? Journal of Social Research \& Policy 4 (2): 107-136.

Gracia, Francisco, Jose Ramos, Jose Maria Peiró, Amparo Caballer, and Beatriz Sora. 2011. "Job attitudes, behaviours and well-being among different types of temporary workers in Europe and Israel.” International Labour Review 150 (3-4): 235-254.

Green, Colin P., and John S. Heywood. 2011. "Flexible contracts and subjective wellbeing." Economic Inquiry 49 (3): 716-729.

Green, Colin, Parvinder Kler, and Gareth Leeves. 2010. "Flexible contract workers in inferior jobs: reappraising the evidence." British Journal of Industrial Relations 48 (3): 605-629.

Hardy, Derrylea J., and Robyn J. Walker. 2003. "Temporary but seeking permanence: a study of New Zealand temps.” Leadership \& Organization Development Journal 24 (3): 141-152.

Henley, Julia R., and Susan J. Lambert. 2014. "Unpredictable work timing in retail jobs: implications for employee work-life conflict.” Industrial and Labor Review 67 (3): 986-1016.

Houseman, Susan N. 2001. "Why employers use flexible staffing arrangements: evidence from an establishment survey.” Industrial and Labor Relations Review 55 (1): 149-170.

Jacobs, Anna W., and Irene Padavic. 2015. "Hours, scheduling and flexibility for women in the US low-wage labour Force.” Gender, Work and Organization 22 (1): 67-86.

Katz, Lawrence F., and Alan B. Kreuger. 2016. "The rise and nature of alternative work arrangements in the United States, 1995-2015. National Bureau of Economic Research. 
Katz, Lawrence F., and Alan B. Kreuger. 2017. "The Role of Unemployment in the Rise of Alternative Work Arrangements.” 107 (5): 388 -392.

Krausz, Moshe, Tamar Brandwein, and Shaul Fox. 1995. "Work attitudes and emotional responses to permanent, voluntary and involuntary temporary-help employees: an exploratory study.” Applied Psychology 44: 217-32.

Marler, Janet H., Melissa W. Barringer, and George T. Milkovich. 2002. "Boundaryless and traditional contingent employees: worlds apart.” Journal of Organizational Behavior 23 (4): 425453.

Marler, Janet H., and Phyllis Moen. 2005. “Alternative employment arrangements: a gender perspective.” Sex Roles 52 (5/6): 337-349.

McKinsey Global Institute, 2016. “Independent work: choice, necessity and the gig economy.”

McNall, Laurel A., Aline D. Masuda, and Jessica M. Nicklin. 2010. “Flexible work arrangements, job satisfaction, and turnover intentions: the mediating role of work-to-family enrichment. The Journal of Psychology 144 (1): 61-81.

Morris, Michael D. S., and Alexander Vekker. 2001. "An alternative look at temporary workers, their choices, and the growth in temporary employment." Journal of Labor Research 22 (2): 373390.

Origo, Federica, and Laura Pagani. 2009. 'Flexicurity and job satisfaction in Europe: the importance of perceived and actual job stability for well-being at work.” Labour Economics 16 (5): 547-555.

Pinsof, Jennifer. 2016. “A New Take on an Old Problem: Employee Misclassification in the Modern Gig-Economy.” 22(34): 2016.

Polivka, Anne E. 1996. “Into contingent and alternative employment: by choice?” Monthly Labor Review 119 (10): 55-74.

Rollero, Chiara, Angela Fedi, and Norma De Piccoli. 2016. “Gender or occupational status: what counts more for well-being at work? Social Indicators Research 128 (2): 467-480.

Silla, Inmaculada, Francisco J. Gracia, and Jose Maria Peiró. 2005. "Job insecurity and healthrelated outcomes among different types of temporary workers." Economic and Industrial Democracy 26 (1): 89-117.

Smith, Tom W., Peter V. Marsden, and Michael Hout. 2015. General Social Surveys, 19722014, [machine-readable data file] /Principal Investigator, Smith, Tom W.; Co-Principal Investigators, Peter V. Marsden and Michael Hout; Sponsored by National Science Foundation. - 
-NORC ed.--Chicago: National Opinion Research Center. 1 data file (59,599logical records) + 1 codebook (3,505pp.).--(National Data Programfor the Social Sciences, no. 23).

Sloane P.J., and H. Williams. 2000. “Job Satisfaction, Comparison Earnings, and Gender.” Labour 14: 473-502.

Sverke, Magnus, Johnny Hellgren, and Katharina Näswall. 2002. "No security: A meta-analysis and review of job insecurity and its consequences”. Journal of Occupational Health Psychology 7 (3): $242-264$.

Tan, Hwee-Hoon, and Chwee-Pen Tan. 2002. “Temporary employees in Singapore: what drives them?” The Journal of Psychology 136 (1): 83-102.

Tannous, Kathy, and Meg Smith. 2013. "Access to full-time employment: does gender matter?" Australian Journal of Labour Economics 16 (2): 237-257.

Theodossiou, Ioannis, and Efi Vasileiou. 2007. "Making the risk of job loss a way of life: does it affect job satisfaction?" Research in Economics 61 (2): 71-83.

Van der Meer, Peter H., and Rudi Wielers. 2013. “What makes workers happy?” Applied Economics 45 (3): 357-368.

van Praag, Bernard, Paul Frijters, and Ada Ferrer-i-Carbonell. 2003. "The anatomy of subjective well-being." Journal of Economic Behavior and Organization 51 (1): 29-49.

Vosko, Leah F, Nancy Zukewich, and Cynthia Cranford. 2003. "Precarious jobs: A new typology of employment.” Perspectives 4 (10): 16-26.

Warren, Tracy. 2004. “Working part-time: achieving a successful ‘work-life’ balance?” British Journal of Sociology 55 (1): 99-122.

Watson, Ian. 2005. "Contented workers in inferior jobs? Re-assessing casual employment in Australia.” The Journal of Industrial Relations 47 (4): 371-92.

Wilkin, Christa L. 2013. “I can’t get no job satisfaction: meta-analysis comparing permanent and contingent workers. Journal of Organizational Behavior 34 (1): 46-64.

Winder, Katie L. 2009. “Flexible scheduling and the gender wage gap.” The B.E. Journal of Economic Analysis and Policy 9 (1): 1-25.

Wooden, Mark, and Diana Warren. 2004. "Non-standard employment and job satisfaction: evidence from the HILDA Survey. The Journal of Industrial Relations 46 (3): 275-97.

Wooden, Mark, Diana Warren, and Robert Drago. 2009. "Working time mismatch and subjective well-being." British Journal of Industrial Relations 47 (1): 147-179. 
Appendix 1: Variable List

\begin{tabular}{|c|c|}
\hline VARIABLE & VALUE \\
\hline \multicolumn{2}{|l|}{ Dependent } \\
\hline JOBSAT & $\begin{array}{l}\text { Job Satisfaction, = } 4 \text { if very satisfied, = } 3 \text { if moderately satisfied, } \\
=2 \text { if a little dissatisfied, = } 1 \text { if very dissatisfied }\end{array}$ \\
\hline HAPPY & $\begin{array}{l}\text { Overall Happiness = } 3 \text { if very happy, = } 2 \text { if pretty happy, = } 1 \text { if not } \\
\text { too happy }\end{array}$ \\
\hline \multicolumn{2}{|l|}{ Independent } \\
\hline INDSELF & $\begin{array}{l}=1 \text { if individual is an independent contractor or self-employed } \\
\text { other, = } 0 \text { if otherwise }\end{array}$ \\
\hline NOCONTROL & $\begin{array}{l}=1 \text { if individual is on-call, temporary help, or contract company } \\
\text { worker, }=0 \text { if otherwise }\end{array}$ \\
\hline REGULAR* & $\begin{array}{l}=1 \text { if individual is in regular, traditional employment, }=0 \text { if } \\
\text { otherwise }\end{array}$ \\
\hline MPROFF & $=1$ if managerial or professional, $=0$ if otherwise \\
\hline FEMALE & $=1$ if female, $=0$ if male \\
\hline YEARSJOB & Number of years in the same job \\
\hline AVHOURS & $=$ Hours usually worked in a week \\
\hline FAIREARNINGS & $=1$ if individual considers earnings to be fair, $=0$ if otherwise \\
\hline JOBINT & $=1$ if family often interferes with job, $=0$ if otherwise \\
\hline JSECURITY & $\begin{array}{l}=1 \text { if "Job security is good" is very true or somewhat true, }=0 \text { if } \\
\text { not too true or not at all true }\end{array}$ \\
\hline GOODFR & $\begin{array}{l}=1 \text { if "fringes are good" is very true or true, }=0 \text { if not too true or } \\
\text { not true at all }\end{array}$ \\
\hline ODDWRKSCHED & $=1$ if "have an odd work schedule", = 0 if otherwise \\
\hline EASYTIMEOFF & $=1$ if taking time off from work is not hard at all, $=0$ if otherwise \\
\hline FAMNOINTWORK & $=1$ if family does not interfere with work, $=0$ if otherwise \\
\hline AGE & Age in years \\
\hline WHITE & $=1$ if white, $=0$ if otherwise \\
\hline MAR & $\begin{array}{l}=1 \text { if married, = } 0 \text { if separated, widowed, divorced, or never } \\
\text { married }\end{array}$ \\
\hline GHEALTH & $\begin{array}{l}=1 \text { if health is generally excellent, very good, or good, = } 0 \text { if fair } \\
\text { or poor }\end{array}$ \\
\hline BAPLUS & $=1$ if a bachelor's degree or higher, $=0$ if otherwise \\
\hline CONINCTH & Family income in thousands of dollars \\
\hline CHILDS & $=$ number of children \\
\hline CHILDSQ & $=$ number of children squared \\
\hline TWOJOB & $=1$ if individual has second job, $=0$ if otherwise \\
\hline Y2006* & $=1$ if the year is $2006,=0$ if otherwise \\
\hline Y2010 & $=1$ if the year is $2010,=0$ if otherwise \\
\hline Y2014 & $=1$ if the year is $2014,=0$ if otherwise \\
\hline
\end{tabular}

*NOTE: Omitted variables are Y2006 and REGULAR workers 
Appendix 2: Regression Results

Dependent Variable: Job Satisfaction

A. Entire Sample

\begin{tabular}{|c|c|c|}
\hline Variable & Ordered Probit & OLS \\
\hline$\overline{\text { MPROFF }}$ & $0.153^{* * *}$ & $0.096 * * *$ \\
\hline FEMALE & $0.149 * * *$ & $0.079 * * *$ \\
\hline INDSELF & $0.463 * * *$ & $0.244^{* * *}$ \\
\hline NOCONTROL & 0.110 & 0.050 \\
\hline MAR & 0.034 & 0.026 \\
\hline CHILDS & $0.073 * *$ & $0.039 * *$ \\
\hline CHILDSQ & -0.003 & -0.001 \\
\hline AGE & $0.006 * * *$ & $0.003 * * *$ \\
\hline CONINCTH & $0.002 * * *$ & $0.001 * * *$ \\
\hline WHITE & $0.206^{* * *}$ & $0.110 * * *$ \\
\hline GHEALTH & $0.186^{* * *}$ & $0.097 * * *$ \\
\hline TWOJOB & $-0.135 * *$ & $-0.070 * *$ \\
\hline FAIREARNINGS & $0.207 * * *$ & $0.109 * * *$ \\
\hline JOBINT & $0.227 * * *$ & $0.132 * * *$ \\
\hline JSECURITY & $0.700 * * *$ & $0.478 * * *$ \\
\hline GOODFR & $0.389 * * *$ & $0.238 * * *$ \\
\hline ODDWORKSCHED & $0.091 *$ & 0.048 \\
\hline EASYTIMEOFF & $0.221 * * *$ & $0.132 * * *$ \\
\hline FAMNOINTWORK & 0.053 & 0.022 \\
\hline AVHOURS & $0.006^{* * *}$ & $0.003 * * *$ \\
\hline YEARSJOB & 0.004 & 0.002 \\
\hline Y2010 & 0.010 & 0.002 \\
\hline Y2014 & 0.051 & 0.021 \\
\hline CONSTANT & & $1.878 * * *$ \\
\hline $\mathrm{JSAT}=1$ & $0.243^{* *}$ & \\
\hline $\mathrm{JSAT}=2$ & $0.960 * * *$ & \\
\hline $\mathrm{JSAT}=3$ & $2.544 * * *$ & \\
\hline Adjusted R2 & & 0.188 \\
\hline Chi-Square & $725.32 * * *$ & \\
\hline
\end{tabular}




\section{Dependent Variable: Job Satisfaction}

B. By Gender

Ordered Probit

\begin{tabular}{|c|c|c|c|c|}
\hline Variable & Female & Male & Female & Male \\
\hline MPROFF & $0.238 * * *$ & 0.120 & $0.139 * * *$ & $0.083 * *$ \\
\hline MPROFFIC & $0.400 * *$ & $0.284 * *$ & $0.216 * * *$ & $0.125^{*}$ \\
\hline MPROFFNC & -0.193 & 0.366 & -0.084 & 0.211 \\
\hline NMPIC & $0.577 * * *$ & $0.507 * * *$ & $0.319 * * *$ & $0.263 * * *$ \\
\hline NMPNC & 0.117 & 0.107 & 0.051 & 0.039 \\
\hline MAR & $0.158 * *$ & -0.089 & $0.090 * *$ & -0.036 \\
\hline CHILDS & $0.106 * *$ & 0.064 & $0.065 * *$ & 0.026 \\
\hline CHILDSQ & -0.011 & 0.002 & -0.007 & 0.002 \\
\hline AGE & $0.006 * *$ & $0.005 *$ & $0.003 * *$ & $0.004 * *$ \\
\hline CONINCTH & 0.000 & $0.003 * * *$ & 0.000 & $0.001 * * *$ \\
\hline WHITE & $0.280 * * *$ & 0.107 & $0.152^{* * *}$ & 0.053 \\
\hline GHEALTH & $0.254 * * *$ & $0.123 * *$ & $0.129 * * *$ & $0.066 * *$ \\
\hline TWOJOB & -0.123 & $-0.159 * *$ & -0.067 & $-0.081 * *$ \\
\hline FAIREARNINGS & $0.185 *$ & $0.238 * *$ & $0.109 *$ & $0.117 * *$ \\
\hline JOBINT & $0.250 * * *$ & $0.208 * * *$ & $0.151^{* * *}$ & $0.115 * * *$ \\
\hline JSECURITY & $0.772 * * *$ & $0.630 * * *$ & $0.531 * * *$ & $0.416 * * *$ \\
\hline GOODFR & $0.417 * * *$ & $0.353 * * *$ & $0.257 * * *$ & $0.214 * * *$ \\
\hline ODDWRKSCHED & -0.073 & $0.260 * * *$ & -0.052 & $0.149 * * *$ \\
\hline EASYTIMEOFF & $0.220 * * *$ & $0.250 * * *$ & $0.130 * * *$ & $0.146 * * *$ \\
\hline FAMNOINTWORK & 0.054 & 0.068 & 0.023 & 0.030 \\
\hline AVHOURS & $0.005 * *$ & $0.007 * * *$ & $0.003 * *$ & $0.004 * * *$ \\
\hline YEARSJOB & 0.004 & 0.003 & 0.002 & 0.002 \\
\hline Y2010 & 0.031 & -0.014 & 0.016 & -0.013 \\
\hline Y2014 & $0.150 * *$ & -0.064 & $0.075 * *$ & -0.042 \\
\hline CONSTANT & & & $1.833^{* * *}$ & $1.988 * * *$ \\
\hline $\mathrm{JSAT}=1$ & $0.338 * *$ & 0.018 & & \\
\hline $\mathrm{JSAT}=2$ & $1.028 * * *$ & $0.781 * * *$ & & \\
\hline $\mathrm{JSAT}=3$ & $2.576 * * *$ & $2.421 * * *$ & & \\
\hline Adjusted R2 & & & 0.21 & 0.174 \\
\hline $\begin{array}{l}\text { Chi-Square } \\
\text { Significance ***1\%, }\end{array}$ & $\begin{array}{l}430.45 * * * \\
* 10 \%\end{array}$ & $340.55 * * *$ & & \\
\hline
\end{tabular}


Dependent Variable: Overall Happiness

C. Entire Sample

\begin{tabular}{|c|c|c|}
\hline Variable & Ordered Probit & OLS \\
\hline$\overline{\text { MPROFF }}$ & $0.110^{* *}$ & $0.054^{* *}$ \\
\hline FEMALE & $0.156^{* * *}$ & $0.076 * * *$ \\
\hline INDSELF & 0.071 & 0.034 \\
\hline NOCONTROL & -0.096 & 0.048 \\
\hline MAR & $0.530 * * *$ & $0.260 * * *$ \\
\hline CHILDS & 0.011 & 0.006 \\
\hline CHILDSQ & -0.005 & -0.002 \\
\hline AGE & $-0.009 * * *$ & $-0.004 * * *$ \\
\hline CONINCTH & $0.002 * * *$ & $0.001^{* * *}$ \\
\hline WHITE & 0.022 & 0.010 \\
\hline GHEALTH & $0.374 * * *$ & $0.184 * * *$ \\
\hline TWOJOB & 0.059 & 0.030 \\
\hline FAIREARNINGS & $0.237 * * *$ & $0.114^{* * *}$ \\
\hline JOBINT & $0.105^{* *}$ & $0.051 * *$ \\
\hline JSECURITY & $0.296 * * *$ & $0.147 * * *$ \\
\hline GOODFR & $0.140 * * *$ & $0.068 * * *$ \\
\hline ODDWORKSCHED & 0.031 & 0.015 \\
\hline EASYTIMEOFF & 0.070 & 0.035 \\
\hline FAMNOINTWORK & $0.110 * *$ & $0.053 * * *$ \\
\hline AVHOURS & 0.000 & 0.000 \\
\hline YEARSJOB & $0.005^{*}$ & $0.002 *$ \\
\hline Y2010 & $-0.120 * *$ & $-0.059 * *$ \\
\hline Y2014 & 0.066 & 0.031 \\
\hline CONSTANT & & $1.710 * * *$ \\
\hline HAPPINESS = 1 & $-0.377 * * *$ & \\
\hline HAPPINESS $=2$ & $1.561 * * *$ & \\
\hline Adjusted R2 & & 0.132 \\
\hline Chi-Square & $533.963^{* * *}$ & \\
\hline
\end{tabular}




\section{Dependent Variable: Overall Happiness}

D. By Gender

Ordered Probit

\begin{tabular}{|c|c|c|c|c|}
\hline Variable & Female & Male & Female & Male \\
\hline MPROFF & $0.180 * * *$ & 0.033 & $0.086^{* * *}$ & 0.027 \\
\hline MPROFFIC & -0.022 & -0.059 & -0.009 & 0.029 \\
\hline MPROFFNC & 0.141 & 0.703 & 0.065 & -0.045 \\
\hline NMPIC & $0.261 * *$ & -0.023 & $0.124 * *$ & -0.012 \\
\hline NMPNC & -0.216 & -0.096 & -0.105 & -0.049 \\
\hline MAR & $0.530 * * *$ & $0.537 * * *$ & $0.254 * * *$ & $0.268^{* * *}$ \\
\hline CHILDS & -0.032 & $0.537 * * *$ & -0.016 & 0.027 \\
\hline CHILDSQ & 0.004 & -0.013 & 0.002 & -0.006 \\
\hline AGE & -0.004 & $-0.014 * * *$ & -0.002 & $-0.007 * * *$ \\
\hline CONINCTH & $0.002 * *$ & $0.003 * * *$ & $0.001 * *$ & $0.001^{* * *}$ \\
\hline WHITE & 0.039 & -0.029 & 0.017 & -0.014 \\
\hline GHEALTH & $0.439 * * *$ & $0.307^{* * *}$ & $0.210^{* * *}$ & $0.153^{* * *}$ \\
\hline TWOJOB & -0.54 & $0.151^{* *}$ & -0.025 & $0.075^{* *}$ \\
\hline FAIREARNINGS & 0.226 & $0.246 * *$ & $0.107 * *$ & $0.120^{* *}$ \\
\hline JOBINT & 0.096 & $0.113 *$ & 0.046 & $0.056 *$ \\
\hline JSECURITY & $0.308 * * *$ & $0.238 * * *$ & $0.148 * * *$ & $0.143^{* * *}$ \\
\hline GOODFR & $0.113^{*}$ & $0.151^{* *}$ & $0.054 *$ & $0.076^{* *}$ \\
\hline ODDWORKSCHED & -0.062 & 0.120 & -0.030 & 0.060 \\
\hline EASYTIMEOFF & $0.104 *$ & 0.046 & $0.050 *$ & 0.023 \\
\hline FAMNOINTWORK & $0.133 * *$ & 0.095 & $0.063 * *$ & 0.046 \\
\hline AVHOURS & -0.001 & 0.002 & 0.000 & 0.001 \\
\hline YEARSJOB & -0.001 & $0.010 * * *$ & 0.000 & $0.005^{* * *}$ \\
\hline Y2010 & -0.045 & $-0.176 * *$ & -0.022 & $-0.088 * *$ \\
\hline Y2014 & $0.144 * *$ & 0.015 & $0.066^{* *}$ & 0.007 \\
\hline CONSTANT & & & $1.71^{* * *}$ & $1.811^{* * *}$ \\
\hline HAPPINESS = 1 & $-0.384 * *$ & $-0.572 * * *$ & & \\
\hline HAPPINESS $=2$ & $1.612^{* * *}$ & $1.332^{* * *}$ & & \\
\hline Adjusted R2 & & & 0.14 & 0.126 \\
\hline Chi-Square & $305.57 * * *$ & $257.33^{* * *}$ & & \\
\hline
\end{tabular}


Table 1: Job Satisfaction Cross Tabulations

By Work Type Only

\begin{tabular}{lc|c|c}
\hline OUTCOME & INDSELF & NOCONTROL & REGULAR \\
\hline Very Satisfied & $60 \%$ & $38 \%$ & $43 \%$ \\
Moderately Satisfied & $34 \%$ & $47 \%$ & $46 \%$ \\
Little Dissatisfied & $4 \%$ & $7 \%$ & $8 \%$ \\
Very Dissatisfied & $2 \%$ & $8 \%$ & $3 \%$ \\
\hline
\end{tabular}

\section{By Gender Only}

\begin{tabular}{lc|c}
\hline OUTCOME & MALE & FEMALE \\
\hline Very Satisfied & $43 \%$ & $47 \%$ \\
Moderately Satisfied & $46 \%$ & $42 \%$ \\
Little Dissatisfied & $8 \%$ & $7 \%$ \\
Very Dissatisfied & $3 \%$ & $3 \%$ \\
\hline
\end{tabular}

\section{By Occupation Only}

\begin{tabular}{lc|c}
\hline OUTCOME & MPROFF & NMP \\
\hline Very Satisfied & $51 \%$ & $42 \%$ \\
Moderately Satisfied & $42 \%$ & $45 \%$ \\
Little Dissatisfied & $5 \%$ & $8 \%$ \\
Very Dissatisfied & $1 \%$ & $4 \%$ \\
\hline
\end{tabular}


Table 2: Descriptive Statistics: Cross Tabulations and Averages

By Work Type and Gender

\begin{tabular}{lcc|cc|cc} 
& \multicolumn{2}{c}{ INDSELF } & \multicolumn{2}{c}{ NOCONTROL } & \multicolumn{2}{c}{ REGULAR } \\
\hline VARIABLE & MALE & FEMALE & MALE & FEMALE & MALE & FEMALE \\
\hline Married & $54 \%$ & $51 \%$ & $42 \%$ & $38 \%$ & $52 \%$ & $45 \%$ \\
Manager/Prof. & $39 \%$ & $36 \%$ & $15 \%$ & $28 \%$ & $32 \%$ & $41 \%$ \\
College Educated & $41 \%$ & $34 \%$ & $18 \%$ & $29 \%$ & $34 \%$ & $34 \%$ \\
Race (White) & $83 \%$ & $78 \%$ & $70 \%$ & $66 \%$ & $77 \%$ & $73 \%$ \\
Have 2 Jobs & $21 \%$ & $19 \%$ & $18 \%$ & $20 \%$ & $19 \%$ & $13 \%$ \\
Job Secure & $84 \%$ & $82 \%$ & $76 \%$ & $76 \%$ & $88 \%$ & $87 \%$ \\
Fair Earnings & $10 \%$ & $11 \%$ & $6 \%$ & $4 \%$ & $10 \%$ & $8 \%$ \\
Job Interrupts & $50 \%$ & $53 \%$ & $52 \%$ & $65 \%$ & $52 \%$ & $58 \%$ \\
Good Fringe & $63 \%$ & $58 \%$ & $55 \%$ & $54 \%$ & $77 \%$ & $72 \%$ \\
Odd Work Sch & $31 \%$ & $32 \%$ & $22 \%$ & $24 \%$ & $14 \%$ & $12 \%$ \\
Easy Time Off & $72 \%$ & $74 \%$ & $61 \%$ & $65 \%$ & $72 \%$ & $71 \%$ \\
Family No Interfere & $65 \%$ & $56 \%$ & $66 \%$ & $67 \%$ & $73 \%$ & $72 \%$ \\
Averages & & & & & & 1.58 \\
\# of Children & 1.78 & 1.76 & 1.37 & 2.00 & 1.48 & 41.96 \\
Age & 47.66 & 45.74 & 40.71 & 41.27 & 41.02 & 7.28 \\
Years on Job & 12.40 & 7.6 & 4.74 & 3.41 & 7.61 & 51,468 \\
Fam. Income (\$) & 72,678 & 57,185 & 45,716 & 36,604 & 59,551 & 40.27 \\
Avg. Hours & 45.15 & 35.69 & 40.23 & 31.40 & 46.04 & \\
\hline
\end{tabular}

By Work Type and Occupation

INDSELF

NOCONTROL

\begin{tabular}{lcc|cc|cc}
\hline VARIABLE & MPROFF & NMP & MPROFF & NMP & MPROFF & NMP \\
\hline Male & $61 \%$ & $58 \%$ & $45 \%$ & $65 \%$ & $38 \%$ & $48 \%$ \\
Married & $62 \%$ & $47 \%$ & $41 \%$ & $40 \%$ & $54 \%$ & $44 \%$ \\
College Educated & $64 \%$ & $22 \%$ & $61 \%$ & $13 \%$ & $64 \%$ & $17 \%$ \\
Race (White) & $86 \%$ & $78 \%$ & $78 \%$ & $66 \%$ & $80 \%$ & $72 \%$ \\
Have 2 Jobs & $22 \%$ & $18 \%$ & $22 \%$ & $18 \%$ & $16 \%$ & $15 \%$ \\
Job Secure & $87 \%$ & $81 \%$ & $86 \%$ & $74 \%$ & $87 \%$ & $87 \%$ \\
Fair Earnings & $5 \%$ & $14 \%$ & $2 \%$ & $6 \%$ & $8 \%$ & $9 \%$ \\
Job Interrupts & $46 \%$ & $55 \%$ & $61 \%$ & $56 \%$ & $47 \%$ & $60 \%$ \\
Good Fringe & $67 \%$ & $57 \%$ & $59 \%$ & $54 \%$ & $81 \%$ & $71 \%$ \\
Odd Work Sch & $36 \%$ & $29 \%$ & $24 \%$ & $23 \%$ & $9 \%$ & $15 \%$ \\
Easy Time Off & $75 \%$ & $72 \%$ & $63 \%$ & $63 \%$ & $73 \%$ & $71 \%$ \\
Family No Interfere & $60 \%$ & $62 \%$ & $75 \%$ & $64 \%$ & $67 \%$ & $76 \%$ \\
Averages & & & & & & \\
\# of Children & 1.71 & 1.81 & 1.57 & 1.63 & 1.41 & 1.61 \\
Age & 48.51 & 45.90 & 43.16 & 40.37 & 43.13 & 40.62 \\
Years on Job & 11.46 & 9.86 & 6.04 & 3.76 & 8.12 & 7.03 \\
Fam. Income (\$) & 87,136 & 53,979 & 55,509 & 38,801 & 72,520 & 44,998 \\
Avg. Hours & 40.65 & 41.72 & 35.18 & 37.17 & 44.00 & 42.18 \\
\hline
\end{tabular}


Table 3: Overall Happiness Cross Tabulations

\section{By Work Type Only}

\begin{tabular}{lc|c|c}
\hline OUTCOME & INDSELF & NOCONTROL & REGULAR \\
\hline Very Happy & $34 \%$ & $25 \%$ & $29 \%$ \\
Pretty Happy & $53 \%$ & $54 \%$ & $61 \%$ \\
Not Too Happy & $12 \%$ & $21 \%$ & $10 \%$ \\
\hline
\end{tabular}

\section{By Gender Only}

\begin{tabular}{lc|c}
\hline OUTCOME & MALE & FEMALE \\
\hline Very Happy & $29 \%$ & $30 \%$ \\
Pretty Happy & $59 \%$ & $60 \%$ \\
Not Too Happy & $12 \%$ & $10 \%$ \\
\hline
\end{tabular}

\section{By Occupation}

\begin{tabular}{lc|c}
\hline OUTCOME & MPROFF & NMP \\
\hline Very Happy & $35 \%$ & $27 \%$ \\
Pretty Happy & $58 \%$ & $60 \%$ \\
Not Too Happy & $7 \%$ & $13 \%$ \\
\hline
\end{tabular}

